\title{
The Impossible Confinement of Nuclear Work
}

Professional and Family Experiences of Subcontracted Workers Exposed to Radioactivity

\section{Marie Ghis Malfilatre}

Translator. Juliette Rogers

\section{(2) OpenEdition Journals}

\section{Electronic version}

URL: http://journals.openedition.org/travailemploi/7640

DOI: 10.4000/travailemploi.7640

ISSN: 1775-416X

\section{Publisher}

DARES - Ministère du Travail

\section{Printed version}

Date of publication: 30 December 2017

Number of pages: 103-125

ISSN: 0224-4365

\section{Electronic reference}

Marie Ghis Malfilatre, "The Impossible Confinement of Nuclear Work", Travail et Emploi [Online], Horssérie | 2017, Online since 11 July 2019, connection on 13 April 2021. URL: http://

journals.openedition.org/travailemploi/7640 ; DOI: https://doi.org/10.4000/travailemploi.7640 


\title{
The Impossible Confinement of Nuclear Work Professional and Family Experiences of Subcontracted Workers Exposed to Radioactivity*
}

\author{
Marie Ghis Malfilatre**
}

\begin{abstract}
Based on an ethnographic study attentive to biographical careers, this article concerns how employees of subcontracting companies in the electro-nuclear industry and their female life partners relate to an occupation characterized by significant geographical mobility and an intrinsic exposure to radioactivity. These young men and couples invest in this line of work as an opportunity that requires a particularly delicate management of life outside of work for both members of the couple. Tolerated and managed for a time, it sometimes proves inadequate for averting occupational strain on the worker, and may even be a source of strain on the family. While workers and their partners are busy holding the relationship together despite the travel demands of the job, which prove to be increasingly burdensome, initially invisible workplace hazards end up causing problems and worry at home. Friends and family are once again exposed to the strains of nuclear work, and their support proves to be determinant as much in the dynamics of mobilizations for workplace health protection as in withstanding the ordeal of occupational illness.
\end{abstract}

\footnotetext{
lthough the topic of workplace health has had some exposure in academic, media, and political arenas in recent years, including the asbestos scandal (HENRY, 2007), musculoskeletal problems (HATZFELD, 2009), and psycho-social risks (CLOT, 2010), there has been little attention to the health issues of nuclear industry employees.

* Translation: Juliette Rogers.

Article published in French in Travail et Emploi, no 147, juillet-septembre 2016.

The research leading to this paper was funded by a doctoral grant from DIM Gestes (2012-2015; DIM Gestes is a research group on work and workplace suffering). I am particularly grateful to Alexandra Bidet, Frédéric Décosse, Adèle Momméja, Joan Stavo-Debauge and Annie Thébaud-Mony for their rich readings and critique that allowed me to significantly revise this article. I also thank the anonymous readers for Travail et Emploi.

** École des hautes études en sciences sociales (EHESS), Centre d'étude des mouvements sociaux (CEMS), Institut Marcel Mauss; ma.ghismalfilatre@yahoo.fr.
} 
Since the opening of its first nuclear facilities, Électricité de France (EDF, the French electrical utility company) chose to entrust some (or all, since the late 1980s) of their maintenance procedures -the work presenting the greatest work-related hazards-to subcontractors. ${ }^{1}$ This in turn led to the creation of "subcontracted" working, health, and legal conditions (ThÉBAUd-Mony, 1991, 2000; DAUBAS-LETOURnEUX, ThÉBAud-Mony, 2001; Bouffartigue et al., 2010), which have already given rise to a string of alerts, reports, and recommendations. Despite several ups and downs, this multifaceted problem has not stabilized or even been recognized as such (CEFAÏ, TERZI, 2012). Union organizations only rarely rank subcontracting and the issues arising from the subcontracting and workplace-health connection among their priorities (GHIS MALFILATRE, 2017). Those who are the most directly concerned, who do not immediately see the connections between health and work, remain quiet on the subject (GollaC, VOLKOFF, 2006), and the troubling victims of occupational illnesses still have little visibility (JOUZEL, 2009). ${ }^{2}$

Moreover, there are still few social science studies based on direct research with nuclear maintenance employees (ZONABEND, 1989; FoURNIER, 2012), and fewer still addressing workplace health issues. Two of the main studies of nuclear subcontracting and its health consequences -one in sociology (THÉBAUD-Mony, 2000) and another in epidemiology (DoNIOL-SHAW et al., 2001)- examined the relationship between work organization and health as well as the novel perspective of "affective and family life." This dimension assumes particular importance for the study of this sector, which requires considerable geographical mobility from workers required to take "long trips" for work throughout the year (Box 1).

In addition to demonstrating the process wherein working conditions become insecure and cancerous toxic hazards are shifted from permanent workers to subcontracted workers, the findings of these studies from the 1990s converge on two other points: the negative experience of a working environment subjected to radiological risk, and the family-life consequences resulting from the constraints of a nomadic lifestyle necessitated by the seasonal nature of maintenance operations for an everrising proportion of workers.

Based on an ethnographic study that paid particular attention to biographical careers (Box 2), this article concerns the relationship that employees of electro-nuclear subcontractors and their female life partners have with this masculine line of work. How do sub-contracted workers and their families experience nuclear work today? How do they stay together? What preoccupations, difficulties, or problems spill from the professional sphere into private life? Although men may use virility as a defensive

1. The two most recent nuclear disasters -Chernobyl in 1986 and Fukushima in 2011- also demonstrated how indispensible human intervention is for basic operations in the case of an accident. In Japan, the employees of subcontractors and temporary workers were mobilized for decontamination work (JoBIN, 2012).

2. For a historical view of processes rendering occupational illnesses invisible, see Paul-André RosENTAL and JeanClaude DEvincK (2007), which reviews the ambivalence of the laws of 1898 and 1919 relative to workplace accidents and occupational illness. 


\section{Box 1}

\section{Outages and "Long Trips"}

The maintenance of nuclear power plants mainly occurs when the reactors are shut down. A continuously operating reactor must be shut down every 12 to 18 months (depending on the type) for planned refuelling, safety checks, maintenance, and repairs. These shutdowns, also called "outages," occur mostly between March and October, when there is less demand for electricity. Its seasonal nature requires a major influx of labour for a short period. Regularly scheduled ten-year visits can require the involvement of over 1,500 workers in a variety of occupations. When not working during outages, subcontractors are hired to work at other nuclear sites (overseen by EDF, Areva, the Commissariat à l'énergie atomique et aux énergies alternatives [Atomic and Alternative Energy Commission - CEA]) and in other industrial sectors (chemical, oil, agro-food), demanding considerable geographical mobility from their employees. This mode of operation keeps employees from their homes for long periods that subcontracting companies refer to as "long trips" (grands déplacements). Like outages, "long trips" may last as long as eight months, March to October. The locations of nuclear reactors often take subcontracted workers hundreds of kilometres from home, and the way that the work is scheduled during outages regularly prohibits them from visiting home for weeks at a time.

\section{Box 2}

\section{Direct Research and Limited Access to Families}

This article is based on a study begun in 2011 on workplace health in the nuclear industry. Taking a three-dimensional ethnographic approach (BIDET et al., 2013), it is intended to be a multifaceted study of interactions related to workplace health in various industry-related arenas, the experiences of people affected or mobilized by such issues, and the dynamic of publicity and damage-control that it engenders.

To do so I conducted research directly with employees of subcontracting companies over the course of five periods of fieldwork at the campgrounds closest to three reactors: four one-month trips and one of two weeks, at different times of the year (spring, summer, and fall, since outages are rarely scheduled for winter). These visits produced a field journal, 37 recorded interviews with subcontracted workers and 4 with workers' partners, and provided the occasion for long and repeated conversations with 4 other women.

In interviews and informal conversations alike, the relationship between nuclear work and the rest of life was omnipresent. The study nonetheless has three limitations in this regard. First of all, the topic will be approached primarily through the experiences and accounts of men. The campgrounds are essentially inhabited by men whose loved ones live too far away for them to see each other at the end of the workday. The presence of wives and partners is rare, that of children even rarer, and when women join men at their work sites it is usually for a short visit. As a result, I rarely had the opportunity to develop contact with women in these masculine living spaces. Moreover, in straying from the strictly defined 
working world to impinge on the sphere of private life, this study (like others before it; SCHWARTZ, 1990) ran into resistance that could only be overcome by building trusting relationships over the long term, which is guaranteed to reduce the number of people included in the study. Lastly, it is also difficult to reach the families of workers that fell victim to occupational illnesses, because telling their story often reminds these men and their families of how intolerable the situation is.

In addition, I conducted roughly 40 interviews with workplace health professionals in the nuclear industry, (former) EDF and CEA employees, representatives from workplace safety committees (CHSCT - Comités d'hygiène, de sécurité et des conditions de travail), occupational physicians, and researchers. Research also included following the progression of several nuclear workers' past or on-going procedures laying claim to their rights (related to their health or recognition of their occupational illness), research on the theme of workplace health in union, medical, parliamentary, and media archives, and observations of a variety of local and national events (union conventions, meetings, and training sessions, CHSCT meetings, press conferences, one-time events).

By varying the scales of analysis and scenes of observation, the resulting materials thus allow us to highlight dynamics that would have been imperceptible without such repeated field immersion and the relationship of trust that was built with employees and unionists mobilised for workplace health.

strategy to deny occupational risk while at work, how do they relate to such risks when they are no longer in the working environment?

This study shows how single workers and young couples see nuclear work as an opportunity that promises economic stability and the possibility of social and familial rootedness, which nonetheless presumes arrangements within the family and the mobilization of female life partners to "make a family." Indispensible to maintaining men in this line of work, these arrangements only provisionally ward off the wear and tear of workers (COTTEREAU, 1983), and may be a drain on family. And while the workers and their loved ones are busy overcoming the challenges of distance to stay together, the initially invisible hazards of nuclear work ultimately raise problems and worry at home, thus compounding the wear of "long trips" and affecting life partners, whose role proves to be equally determinant in the dynamics of health protection mobilizations and facing the ordeal of illness.

\section{Tolerating Mobility and Arrangements for Staying Together}

\section{Accepting "Long Trips" to Earn Money}

Workers' decision to seize the opportunity and commit to a career in nuclear subcontracting (with both its constraints and its promises for the future) is usually rooted in the family trajectory and a geographical situation. Most of the subcontracted 
employees in the study came from rural or suburban working class backgrounds in regions with a nuclear reactor where someone they know worked. When the need to find work, locally available resources, and an opening provided by a friend overlap, it paves the way to nuclear work.

This choice is neither by default nor a defence against unemployment. The nuclear sector can be symbolically and financially rewarding, making it possible to imagine a start in life with a promising future. While the base income for young labourers just starting their career is around $€ 1,200$, employees of nuclear subcontractors with the same qualifications can start out as high as $€ 3,000$ due to various bonuses compensating for the strains of the work: wearing restricting protective suits, intervening in radioactive areas, atypical working hours, and/or "long trips" for outages. Nuclear technology moreover still carries a degree of prestige that gives workers the satisfaction of labouring for the "radiance of France" (НECHT, 2004).

Subcontracted workers travelling for work ordinarily have three housing options. While some go to hotels, others share vacation rental properties or settle into campgrounds near the nuclear facility. The latter (not necessarily those with the lowest incomes) may live in anything from a simple canvas tent to a second-hand campervan to a nice motorhome. An investment in mobile housing makes it possible to economize by saving work-related travel compensation money, but also and more importantly to reconstruct a "home." The Spartan nature of such living spaces in no way undermines the fundamental feeling of truly living somewhere that comes from the personal conviction that one can "relax in complete security" (BREVIGLIERI, 2012, p. 41) and the appreciable independence it gives to people with irregular working hours -all qualities lacking in an impersonal hotel room.

Most of the workers in this study thus opt for a dual-residence strategy. One is the locally rooted family home, the "founding space" related to "a place and a connection, a space and a belonging, a space of cohabitation where a way of being together takes shape" (GotMAn, 1999, p. 73), and the other their mobile housing. They thus build "a life between two territories" (VIGNAL, 2005, p. 113), one stabilised in the social and familial environment, the other instable and determined by occupational imperatives. Trying to take advantage of this lifestyle and manage it as best as possible does not mean renouncing the prospect of a sedentary life, however. The most senior workers have factored geographical mobility as a criterion for their existence, but the younger ones anticipate withdrawing from it as soon as they have reaped sufficient rewards.

Indeed, none of the younger workers speak of a desire to live this way over the long term. Maxime, a 25 year old from Dunkirk, is a case in point. He became a worksite manager for a subsidiary of Areva after earning his BTS ROC degree, ${ }^{3}$ and accepts geographical mobility because it suits a specific step in his career. Maxime has been going on "long trips" for three years, and chose to buy a new campervan that he scrupulously maintains so he will be able to resell it when he wants. He also just took

3. A Brevet de technicien supérieur, the approximate equivalent of an associate's degree, specialised in boiler-making. 
out a 25-year loan with $€ 900$ monthly mortgage payments to buy a house near Dunkirk, where he and his new girlfriend have lived for six months. They hope to "have a baby on the way in the next year," at which time he will stop doing "long trips," "even if it means quitting this job and doing something else," because "Madam complains" that he is away so often and "family life is incompatible with long trips anyway."

As paradoxical as it might seem, in most cases the mobility is intended to lay down roots. Being mobile is the means of creating favourable conditions for the future, where mingle hopes of "founding a family" (in the traditional sense of the term) and building one's own home (rather than having it built) or becoming a homeowner (rather than continuing to rent). Becoming a homeowner seems to be particularly desirable for most of the interviewed people, who did not hesitate to take on debt to make their dream a reality. The important thing is to hold on in the face of the job's inconveniences for a time, "making money" while limiting the sources of dissatisfaction arising from the distance. The constraints of nuclear work are identified and somehow integrated into a life plan where the prospect of giving up "long trips" is always present, and leaving the nuclear industry oftentimes as well. Like the fates of labourers described by Alain Cottereau (1983, p. 103), "what would be intolerable for a future of 30 years of continuous labour becomes tolerable in a short-term plan lasting only a few years."

\section{Arrangements for Family Plans That Are under Construction}

Biographical analysis of the paths of couples met over the course of research makes it possible to comprehend a few constants in the kinds of arrangements they make in order to hold on to both their job and their family plans. Louis and Amalia are instructive in this regard, and their story shows how these arrangements are temporary, and usually very fragile.

Louis began his career in the nuclear industry in 1985, at age 19, after getting his $\mathrm{CAP}^{4}$ degree in mechanics. He was first hired by the nuclear subcontracting company where his three brothers and father already worked, in a reactor being built near their home. He learned logistics work "on the fly," including conditioning nuclear waste, decontamination, and assisting "hot zone" operations. In 1990, the year his first child was born, his employer sent him on the "long trip" circuit. The company lost its contracts with EDF in 1998, and Louis was laid off. He took advantage of the spell of unemployment to try starting his own business (a leisure park), but despite the couple's considerable financial, psychological, and emotional investment, it failed. In 1999 Louis went back to the reactor he knew. The gradual intensification of his union engagement as shop steward and member of the CHSCT representing the Confédération générale du travail (General Confederation of Labour - CGT) labour union ended in his being forbidden entry to the nuclear facility where he was working at the time. A dismissal procedure was initiated in reprisal for his activities, which, as we

4. Certificat d'aptitude professionnelle, a secondary-level vocational degree. 
will see later, involved a union initiative for the respect of rights for health protections and the recognition of occupational illnesses.

Amalia was born in 1967 and grew up in the same village as Louis; their fathers were both textile workers at the time. After passing a secretarial baccalauréat exam, ${ }^{5}$ she became a waitress until the birth of her first child. She then alternated between short-term work contracts with various employers, periods of unemployment, and job training before devoting herself to raising her three children for a time. In the mid-2000s she resumed paid employment to offset the family's financial difficulties. Amalia has a distant relationship with employment: she says she has always "favoured family life" and has never hesitated to "slam the door on an employer" for it.

Louis and Amalia went to the same schools. They began dating as teenagers, but they did not plan on living together until their respective educations were finished. For all that, they both wanted to keep their occupational independence. As a result, Amalia did not immediately give up her waitressing job when her hours came to conflict with Louis'. Despite the de-synchronisation of social times in the couple and the frustrations it produced, this "moratorium period" (TESTENOIRE, 2006, p. 86) makes it possible to gradually experience life together and imagine the possibility of starting a family, in the process seeming to ensure a happy future.

As plans for a family became reality, priorities changed. Since both thought that Louis' employment situation was more advantageous and allowed them to take this new step worry-free, Amalia looked for another job that was more compatible with her responsibilities as a future mother without seeing this adjustment as a source of frustration. The resulting balance manifested what was experienced as a harmonious reconciliation between work and family lives, the distance resulting from "long trips" being seen as an opportunity rather than negatively:

"Oh, wow! At the time he'd get some really appealing trips. Oh, it was cool! It brought us a certain level of comfort. We started going away on vacation, putting money into savings. We also went on little weekend trips here and there, and we conceived our first daughter. The future opened wide for us."

Amalia worked and cared for their daughter, and they were happy to see Louis on weekends. Amalia remembers their lifestyle while Louis was away with a degree of nostalgia ("It was good, the two of us, we had our little routine"). The "long trips" were thus perceived as beneficial for the new and growing household. After the birth of two more children in the following years, the advantages of this separated life were sometimes re-examined. Amalia, who devoted herself entirely to homemaking, ran into problems meeting the needs of the larger family. Overwhelmed, she moreover felt that the second and third children were missing out on the prodigious attention that had been heaped on the first child. The initial consensus over the family's plans was further chipped away when Amalia was obliged to resume paid employment to

5. The approximate equivalent of British A levels. 
deal with the household's financial problems. When asked about their memories of the time during one of our interviews with Amalia at home, the children stayed modestly silent and only soberly said that they were "proud" of their father.

As Louis and Amalia's "family career" (BONNET et al., 2006) illustrates, each step (moving in together, planning a family, birth of the first then subsequent children) requires the renegotiation of each partner's professional time and the organization of domestic life. Each leads to new agreements, at first consenting, but later tacit or under duress. The traditional gendered division of household labour is constrained due to the necessity of male mobility in nuclear maintenance work. It is even harder to challenge this constraint because the job and the arrangements it presupposes were initially beneficial for the couple.

\section{"Making a Family" While Away for Work}

Men's experience of "long trips" depends heavily on how satisfying their nonworking lives are. Those who claim a positive experience are indeed those who manage to reconcile their careers with a solid conjugal life. But since this line of work requires them to be quite mobile, marital stability depends on compromises with their partners, who must accept their husband or partners' absence or regularly visit them at their worksites in order to temporarily recreate the world of home.

From the women's perspective, joining their partners travelling for work can be somewhat pleasant, a chance to "see the country" and share cherished vacation-like moments. When unemployed, on maternity leave, or retired, they sometimes move into campgrounds with their partners. It is even less common for women to come with children, although this is what Aurélie and Laura did when they came from Calais to join their husbands one Easter holiday. Their husbands are brothers, aged 28 and 30 , one an insulator and the other a scaffolder for a subcontractor for EDF that also employs their other two brothers. They were introduced to the work by their father, who works for the same company, despite their mother's reservations; as one of the wives explained, "The mother-in-law didn't want her four sons going into nuclear too, she'd gone through that, she didn't want us to go through the same thing. And she knows that the children miss the men."

Aurélie has two children, aged 3 and 7. Employed on a permanent job contract as a security agent at the port of Calais ("We look for migrants with the [border police]"), she can no longer stand her job and hopes to be able to change soon (her husband alerted her to the possibility of a security agent position at the Gravelines nuclear reactor). As for Laura, she has a 3-year old and will soon give birth to a second child. She is savouring these final weeks of maternity leave, and says she is happy to have been able to reunite with her husband as soon as the school holiday allowed. For four years she has worked part-time on a permanent contract for a major call centre, and she plans on resuming her job at the end of her leave. It will be her last visit to the campground for quite some time, as she does not plan to bring a baby there. 
Both women make visits to the campground to offset the periods of separation as best they can. That the whole sibling group works for the same company moreover allows coordinated trips and material solidarity by sharing meals and clustering camper vans in nearby spaces. This revives a family ambiance during school vacations:

"The children play together during the day, and at night they are so happy to sleep in the same room as mum and dad! It's going to be funny for them when we go back home, vacation's over!"

Not all women have such a positive experience of campground life. Some feel just as isolated there as they do when staying home with one or more pre-schoolers. Véronique is in this situation, an unemployed mother of a 2-year-old boy she will look after full-time until he is old enough for school. Her husband has worked five years for a company as a valve technician, thanks to the help of his uncle and two cousins. His income allows the couple to live off one salary, but Véronique is worried that her son is growing up without his father. Fear of the harmful effects of the father's absence on the child's upbringing and happiness presses her to join Jonathan whenever possible (although sometimes he goes too far away, as happened in 2015 when he was sent to South Africa for two months). She is not enamoured of life at the campground, but her husband seems little troubled by it:

"This summer we spent four weeks at Paluel. It was perfect. She was kind of bored, but I had the little one. When I could I'd come home at noon and she'd cook for me... I was the only one in my company to have my girlfriend here with me. It was great."

Couples primarily look upon the experience of geographical mobility favourably during the early years of life together, at a time when the resources from nuclear work cast a reassuring or promising light on the family's future. This favour is associated with young women with low skill qualifications whose employment opportunities are indeed limited. Their own futures being "put on hold" (PAUGAM, 2007, p. 180) in a way, nuclear work and its financial compensation allow them to withdraw from the world of employment for a while, usually coinciding with motherhood, as Aurélie, Laura, and Véronique's histories illustrate. For these women who had held jobs requiring few qualifications since they were old enough to work, periodically escaping the constraints of employment allows them to "catch their breath." Regardless, they never see their withdrawal from paid employment as permanent, even when they think that their own working conditions are poor and that their spouse's salary would allow it. Even when unemployed, and to the contrary of the expectations of some of their husbands (like Jonathan, who is very satisfied that Véronique is waiting for him at the campground with their son), these young women do not consider themselves to be housewives. They are attached to having a job, active employment being as foundational to their social identity as motherhood (BATTAGLIOLA, 1999). 


\section{From the Constraints of Mobility to Constrained Mobility}

\section{The Impossible Double Life}

The advantages accrued from nuclear work do not always make up for problems arising from a prolonged absence, for the men or their families. One evening my neighbour Fabrice, a subcontracted worker, knocked on my door, which I had left ajar. The day before we had had an interview in which he had shown great enthusiasm for his job. An automation expert for Alstom very engaged in his work, he had filled several pages of my field notebook with sketches explaining his contributions to the worksite in detail, his "real job" (BIDET, 2010). But that evening at my door he had a more serious mien and wanted to modify what he had said the night before. "Actually, in thinking about it again, you could say that we're Zola's miners of the twenty-first century," he said, "we sacrifice our health and family lives for the electrical comfort of the whole country." He had just learned that once again, despite the schedule set at the beginning of the job, he would not be able to go home the following weekend. The maintenance work for which his company had been engaged was running behind, so in order to respect the schedule company superiors had given EDF, workers were required to be flexible to meet their productivity objectives in disregard for their lives outside of work.

There is little leeway for those who try to loosen the stranglehold of professional constraints. Franck is 45 and has worked as a mechanical engineer in the nuclear sector since 2003. While I was interviewing him in his campervan, he got a call from his 14-year-old son. When he hung up, he shared his difficulties in dealing with the divorce he had just gone through and attributed the end of his relationship to the living conditions dictated by nuclear work:

"I got into the long trip circuit to make more money. I didn't go home on weekends because being on call made it possible to increase my income. I was on the road like that eight out of twelve months for several years. When I wanted to slow down and have more time for my family, when I began to turn down being on call, I was threatened, they pressured me."

Complicated situations emerge, leading to delicate arbitration between maintaining a job in the nuclear sector and a family life. Shedding some light on this aspect of mobility is the account of Jean-Luc, a 55-year-old non-destructive testing specialist and union representative for the Confédération française démocratique du travail (French Democratic Confederation of Labour - CFDT). As a member of his village municipal council and a sporting club, he has being trying to reconcile geographical mobility with engagement in a local social life -a rarely observed situation in the study. Indeed most often interviewees regret having had to abandon athletic or associative activities because of the demands of mobility and the nearly complete lack of control over their work schedule. The extraordinary nature of Jean-Luc's political and club engagements is even clearer when he describes the kinds of problems he faced 
when trying to hold his career and participation in local life together. Coming to an arrangement with the conditions of his work-related travel seems to have come at the cost of being penalized in return:

"In 2009 I turned down an offer to be on call. They told me, 'You live in Dunkirk, we're going to send you to Tricastin ${ }^{6}$ next week.' The message was clear-I'd refused a mission, by way of sanction they gave me another even farther away."

Thus the way that nuclear work is organized usually forces its workers to give up on most of the engagements comprising the ordinary fabric of social, affective, familial, and political life. When a lack of control over the time given to work and (implicitly) life outside of work is identified as a problem, it usually proves to be unresolvable. The situations of Fabrice, Franck, and Jean-Luc indeed illustrate the very limited flexibility available to subcontracted workers for managing the conditions of "long trips." No major differences are revealed between their positions in the social division of labour: although Jean-Luc's lower management-level rank may have allowed him to refuse being on call, he thinks he was sanctioned as a result. Likewise, Fabrice, a technician for Alstom, had his weekend family plans fall apart so he could respond to a last-minute demand while he was on call. The imperatives of availability and geographical mobility thus end up being sources of difficulty for employees as well as their families, especially after the birth of children.

\section{The Cost of Prolonged Absences for Families}

The conditions of relative felicity change as new life stages bring new needs and expectations. With the birth of children, the increased burden of family obligations proves to be particularly challenging for these couples with the additional particularity of having to deal with long and repeated periods of separation. This model, where the man's life is organized around paid labour while the woman's combines paid work and family life, is related to the traditional sexual division of labour within the family but further accentuated in this situation by the organization of nuclear work. Although young couples sometimes find satisfactory compromises, the women's role of regulator in the family (BARRÈRE-MAURISSON, 1984) is nonetheless a source of strain in the relationship, especially around the time of the arrival of the first child, and may lead to a breakup.

As the years go by, the experience of mobility does become increasingly difficult to bear. The returns on efforts to hold up under the working conditions that are sometimes experienced as a necessary evil are no longer enough. Long absences and the acrobatic management of social life are wearing, and when employees cannot manage to leave the "long trip" circuit, breaking up the family is sometimes the only option. This was the experience of Frédéric, a mechanic of fifty or so living in a campervan

6. A nuclear plant in southern France, $50 \mathrm{~km}$ north of Avignon, straddling the administrative departments of the Drôme and the Vaucluse. 
near mine. Like the women who worried that their children missed their fathers, he expressed regret that he did not see his daughter grow up. He started to work in the nuclear industry in the mid-1980s and tried to leave it several times, without ever managing to find another steady job:

\begin{abstract}
"With my first wife, we didn't see each other, we lived parallel lives. Not one with the other, but one beside the other. Each of us had our own life. She divorced me. I've got a daughter that I barely know. There is always tension between us, even if we adore each other, but we don't know each other because we didn't live... My good times didn't happen with her, since they happened at [nuclear] plants. And... now I'm living again with another woman, because I remarried, with whom I get along really well. But it's the same: I barely see her. It's not easy, it's also the pleasure of being two, being able to talk, to exchange... there's complicity. If we lose that complicity there's no point."
\end{abstract}

Frédéric makes a direct causal connection between the failure of his first marriage, his strained relationship with his daughter, and the constraints of nuclear work. Although he seems satisfied with his new relationship, he mentions distance affecting it, too. This is how workers on the "long trip" circuit reveal their feeling of insecurity, never sure of being able to return to their families as planned. If it is first seen as a way to "make a family" under good material conditions, nuclear work also causes wear and tear on loved ones. Women are worn down from bearing sole responsibility for children and the house while the household is taking shape, a period of life that only happens once.

Faced with a mobility that turns out to be as difficult to negotiate as it is to maintain over time, disappointments and frustrations build up for both employees and their families. Once having promoted nuclear work, they come to see it under a darker light, one that grows even dimmer when the health risks of their jobs leave the work environment and threaten the home. Although men's geographical mobility makes it possible to buffer these hazards for a time, they do not always remain confined to nuclear sites. More insidious, and with delayed effects, they thus compound the other sources of strain described above, and do not spare the household.

\title{
Family Experiences of Workplace Health Hazards
}

\section{Distance as a Temporary Buffer}

Maintenance workers are those the most exposed to sources of radioactivity: they endure 80 to $90 \%$ of the doses of ionizing radiation received annually in all nuclear facilities across France. ${ }^{7}$ Irradiation and contamination incidents are frequent during

7. This percentage may be based on old studies from the early 1990s (cited in THÉBAUD-MonY, 2000; DONIOL-SHAW et al., 2001) but it still holds true today: it is acknowledged by actors in the nuclear industry and regularly confirmed 
outages, despite the use of many kinds of protection, such as protective suits and biological barriers like airlocks, lead mats, and water. Although some studies have revealed the dynamics through which professional groups exposed to dangerous or arduous working conditions manage to suppress the expression or even consciousness of fear through workplace practices emphasizing virility and courage (DEJOURS, 1993; ZONABEND, 1989; CORTEEL, LE LAY, 2011), employees in the nuclear industry are not "kamikazes" (FouRNIER, 2000). To the contrary, younger workers in particular speak of their fear of the effects of radioactivity on their health (Box 3) and their concern about worrying their friends and family. Rémy, a 32-year-old subcontracted worker assigned to nuclear logistics, is among those anxious to protect their loved ones from all worry by telling them as little as possible:

"Me, my family, my wife, they don't really know what I do at work. She knows that I work in the nuclear sector, period. I don't tell her, there's no point. [...] If I told her stuff she'd think, 'Fuck!' My parents live right next to the plant in Chinon, you can see the reactors from the yard -it's the same, they don't know what happens. They ask me questions... but I avoid telling them."

\section{Box 3}

\section{Ionizing Radiation and Occupational Illness}

There are at least four categories of illnesses and symptoms with known connections to radioactivity: cancers and haematological disorders, reproductive problems and foetal malformations, cardiac disorders, and immunity disorders.

Institutional recognition of radioactivity-induced illnesses varies widely between laws as well as countries, however. Taking cancer as an example: although Table 6 of the list of occupational illnesses recognized by the national health system in France, "Illnesses provoked by ionizing radiation," only addresses three cancerous pathologies and has not been updated since 1984, the 2010 law for the compensation of victims of French nuclear testing acknowledges 21 of them, while American law recognizes 29.

As other studies have shown, getting occupational illnesses officially recognized is a long process involving mechanisms of invisibilization (THÉBAUD-MONY, 1991, 1992), the sedimentation of complex institutional actions and configurations (Boudia, FelLinger, 2007; Boudia, 2009), and social negotiation (Rosental, DEvincK, 2007). Other studies have moreover demonstrated the dynamic and unstable character of "nuclear" as a category, resulting in some working in the sector (African uranium mine workers, for instance) being denied recognition as such until quite recently, meaning they were not informed of the hazards of the work and did not receive protective suits or even appropriate medical oversight (HECHT, 2016).

in annual assessments by the Institut de radioprotection et de sûreté nucléaire (Institute for Radiation Protection and Nuclear Safety - IRSN). 
These gaps between regulation and recognition of occupational illnesses and between countries are more generally tied to the problem of current norms for protection against radiation, which are primarily based on an extrapolation of risk estimates derived from the study of survivors of the atomic bombs in Hiroshima and Nagasaki in August 1945. While survivors of the American bombings received heavy doses of radiation in a fraction of a second, occupational exposure is much lower, repeated, and spread over time. This gap between the model of reference determining protective measures and actual occupational exposures leads many researchers to challenge the legitimacy of the exposure thresholds backed by the International Commission on Radiological Protection (ICRP) and call for an improvement in how "low doses" are taken into consideration.

In fact, the relationship between low doses of radiation and cancer mortality has been scientifically established since the 1970s (DAUBAS-LETOURNEUX et al., 2012) and verified recently in the 2005 publication of an international study conducted by the International Agency for Research on Cancer (IARC) with over 400,000 nuclear facility employees in 15 countries (CARDIS et al., 2005). Since it only addressed one type of disorder (cancer mortality) and only concerned permanent employees of nuclear facilities (whose exposure to ionizing radiation is the weakest of all workers in such sites), the pathogenic effects of low-dose exposure to radioactivity are probably still underestimated.

Consequently, the European Committee on Radiation Risks (ECRR), comprised of independent scientists from the nuclear industry, proposes a new model for interpreting the health effects of radioactivity. Considering that the knowledge accumulated over several decades invalidates the ICRP's reference model, ECRR experts request that the established norms be reduced by a factor of four for workers in the nuclear industry (which would lead to a reduction of the limit thresholds from 20 milliSievert per year [mSv/an] to $5 \mathrm{mSv} / \mathrm{an}$ ), a demand that has been taken up by part of the CGT labour union in France.

The dearth of details on occupational hazards is thus explained by the will to not create a source of worry for loved ones. "There's no point" in making them aware of the dangers because they are no more able to fix it than the workers themselves. Despite having had a contamination accident, Rémy has never broken the rule he made for himself:

"It was at Bugey, a weekend when I was supposed to go home. I'd been in nuclear for three or four years, but I was already foreman at the time. So it was while I was finishing up a worksite, with their notorious system of pressure differential ducts. So you have to compress them to balance them, and uh... I did stand aside, but it must have been a duct that was clearly rotten and I got a load... The duct was completely rotten. It was a site where we'd come just for an outage. You don't know the equipment, you don't know where it's been, like, it happens fast. And then, the whole thing about having to compress the ducts to get them into the barrels, and after, having to pack it down to be able to close the barrels... It's this kind of storage that's not, not great... I got 15,000 becquerels ${ }^{8}$ of cobalt 60 . I had cobalt, silver, anyway

8. A becquerel is a unit of measurement of radioactivity. 
a whole bunch of radionuclide stuff. At any rate I didn't even go through the $\mathrm{C} 3^{9}$ because they all started going off when I was 15 meters away. So then, after, to the infirmary... It turned out that there was internal [contamination], so after that it was 'pee and poo in the cup,' as we say. You stay at the campground for three or four days. They gave me medicine for it to go more quickly, to go to the bathroom. Then once you go to the toilet, you do it in the cup, and after you bring it to anthropo. ${ }^{10}$ Every day you bring your little cup. And after they analysed it to see if there was something in it and they did a follow-up [exam] to see if I still had something; it lasted four days. If you go home, they tell you, 'No [sexual] relations.' They tell you lots of stuff, you don't wanna go back... And then I ended up evacuating it naturally. It was the first time I was internally contaminated -now I pay serious attention."

This quote eloquently communicates the loneliness of dealing with accidental contamination, presupposing invasive medical procedures (being taken away by ambulance, anthropogammametric examinations, isolation until radioactive materials are expelled) and a halt of work that ultimately results in distancing work colleagues as well as friends and family. Although an organizational problem is emphasized ("It's this kind of storage that's not, not great") the event feeds into a feeling of guilt. The accident follow-up procedure comes with a sort of publicity in the plant that is unfavourable to the emergence of solidarity with the victim: co-workers see the contaminated worker as "rotten." Furthermore, the hiring company (EDF in this case) factors the accident into its evaluation of the subcontractor's services upon completion of the work, which is then used to decide whether they will renew the maintenance contract with that subcontractor.

The warnings about the behaviour to adopt with friends and family also fuel this sense of guilt: they must not "pass on" the filth, "no [sexual] relations." To this is added concern for preserving their families from the invisible threat that workers' bodies have come to carry, through no fault of their own. Like sewer and morgue workers that are "afraid of contaminating their family with microbes, viruses that might have settled on (or in) their bodies or clothing" (JEANJEAN, 2011, p. 296), nuclear maintenance workers fear contaminating their families, which makes them anxious. It is most often expressed in silence, workers like Rémy preferring to not talk about their activities at work or the hazards to which they are exposed.

The geographical distance helps to keep loved ones in relative ignorance. Since the contamination occurred in a plant hundreds of kilometres from home, Rémy called

\footnotetext{
9. A radiation detection portal.

10. A nickname nuclear workers give to anthropogammametric analysis, which detects gamma radioactivity in the human body and measures it in becquerels. This analysis is in addition to the chain of radiological monitoring at the exit of the controlled zone (monitoring of hands and feet, radiation detection portals $\mathrm{C} 1, \mathrm{C} 2$, and C3). It is required as part of the medical oversight that delivers and renews the authorization for workers to intervene in a nuclear zone and when internal contamination is suspected. Anthropogammametric analysis makes it possible to diagnose possible contamination by measuring gamma rays from ingested or inhaled radioactive elements and determine the nature and activity of the detected element(s). In case of proven internal contamination, further urine and stool analyses are conducted to track the elimination of the contamination.
} 
off his weekend plans to see his family and stayed alone at the campground waiting for health services to declare a normalized situation. Even when a contamination problem cannot be resolved immediately by medical service intervention and the victim carries radioactivity outside of the nuclear enclosure, geographical distance makes it possible to maintain a relatively airtight barrier between workplace hazards and private life.

\title{
From Risk Perception to Mobilization
}

Workplace hazards do not always remain in the confines of nuclear facilities or the campgrounds where subcontractors' employees live. Things that might have seemed normal or anecdotal accumulate as so many elements that end up shaking their original trust in security rules and norms. The introduction of workplace hazards at home can cause risk perception to shift, as Louis and Amalia's account illustrates. When they moved in together, as we learned earlier, Louis' nuclear work was not a problem, or even a source of worry. The arrival of children led them to take some distance, however.

\begin{abstract}
"After the birth of the first, in the early 1990s, we began to say... Sometimes Louis was... He doesn't have the kind of temperament to be tired, he has a lot of energy, he doesn't sleep a lot, but sometimes he felt really tired and we noticed that it was related to interventions in the zone, when he got a fair bit of radiation. So we wondered, for his own body and those of the children, if that wasn't going to have consequences... It was little things that added up. We became aware that it was dangerous and became aware of the fact that he was maybe putting his life at risk. And then, once he brought some laundry into the house that he'd brought home from work. We washed the laundry, which wasn't supposed to be contaminated, with our own things, and once it ended up that he couldn't re-enter the plant because he had contaminated clothing -I think it was underwear- when it had been washed with our things. So we said, that means that sometimes... Maybe there wasn't a risk in bringing something home, but there was sometimes, still... He still brought certain particles home with him that normally shouldn't be there."
\end{abstract}

A realm of questions and then suspicion opened with the birth of the first child. Louis' fatigue was noticed and considered in relation to his job and the risks he ran during operations with high exposure to radioactivity. The contaminated laundry incident then fed into a new wave of doubt, and distrust of his working conditions settled permanently into their minds. From then on, Amalia wanted "to know" and Louis could contribute his knowledge as a "raw expert" (PITTI, 2010), no longer holding back explanations of the details of his job.

Amalia went into research mode, not only within her relationship (she questioned Louis) but also in an organization for subcontractor employees and their families (where she talked with wives and domestic partners). Louis, some of his co-workers, and some of their partners, who "were starting to see illnesses around them," started gathering evidence and thinking about it, and decided to start an association "because 
the union wasn't doing enough on health issues." Especially touched by the case of a co-worker of Louis' that she had known, Amalia also became active:

"I was really ready to do something because Christian ${ }^{11}$ came to see us several times and I could really see how affected he was and how much he and his wife were suffering."

Amalia supports her husband's cause by actively participating in the association, taking care of its material tasks and attending public meetings with her husband. Defining her role as a "woman in the shadows," she supported him when he first spoke publicly and to this day when he tries to raise awareness of the cause with other publics:

"I stayed in the public, I was listening to what he had to say, and I gave him feedback. He needed that. Because obviously, I see things, I see people's reactions, I watch people, things Louis can't see. [...] Then people come to me and say, 'So, you're the partner...' and they ask me things, things they hadn't understood, and after they ask me how I experience all that, given the risks my husband runs. They say to me, 'You must be constantly on alert!' You see that people are touched by it and it disturbs them."

Amalia also allowed Louis to keep his engagements by resuming paid employment when the family's income dropped. Thanks to this affective and material support, Louis is fully invested in his legal battle for his own rights and those being fought by the union and the association. For all that, the collective mobilization itself leads to another kind of strain. Although the couple appears to have a particularly strong fighting spirit, defending health rights or reparations for occupational illnesses in the context of nuclear subcontracting demands particular tenacity, and they had to endure the repercussions of financial sanctions, the demands of being available for protest work, and the short tempers rising from financial and affective insecurity at home.

\section{Family Reconfiguration When Confronting Illness}

Learning that one has a serious illness is first of all an "event that's difficult to digest," a "shock" that may be a "source of unproductive violence, received as a blow, or even generate nothing less than a trauma" (StAVo-DeBAUge, 2012, p. 191). Research-action studies on legal access in cases of serious pathologies have shown how the news of the illness can be a "staggering factor" for victims and their friends and families (MARCHAND, RolLin, 2015). Moving on from this state of immobility,

\footnotetext{
11. Employed by one of EDF's main subcontractors, Christian Verronneau died on 10 September 2012, of causes related to a radiation-provoked lung cancer that was recognized as an occupational illness by the Caisse primaire d'assurance maladie (Primary Health Insurance Office), a rarity. Christian Verronneau went through this first procedure for recognition with the support of his family, the association founded by Louis and his colleagues, and an anti-nuclear group, and at the same time started gross negligence proceedings against his employer. After his death, some former co-workers supported his family's pursuit of the case, which concluded in April 2016 with the recognition of the company's gross negligence, a first for a nuclear subcontractor.
} 
the victim may set out to find what caused this change in their health from which they suffer (DEWEY, 2010).

Sometimes they take the legal path, a process likely to take several months or years. The steps of the process -recognizing that you are a victim, seeking the responsible party, and demanding reparations- are not self-evident (FELSTINER et al., 1991). When this path is chosen, its route is uncertain and intrinsically tied to the experience of the illness and how it develops. Among the (former) workers engaged in the process of getting recognition for their occupational illness, help from an outsider (family and/ or a union) always turns out to be determinant in spurring the investigative process as well as recovery (Box 4).

Box 4

\section{Julien, Suffering from B-Cell Lymphoma}

Julien is the father of two children, and his partner is a nurse. He started working in the nuclear industry in 1996. After passing his baccalauréat MSMA (specialized in the maintenance of mechanical and automated systems) while doing on-the-job training at EDF, he was hired by a subcontracting company to do logistical work, and then went on the "long trip" circuit. Most of the tasks assigned to him consist of decontamination work (of equipment, spent fuel pools) and dressing and undressing assistance during operations requiring the wearing of protective "Muruoa" suits.

In June 2011, while he was on the road doing maintenance work far from home, he received a strong dose of radiation during the decontamination of a pool. His dose was 3.8 times higher than the anticipated levels of the radiation security regime (RTR). ${ }^{1}$ Julien went back to his rented room after the incident, feeling exhausted but not imagining that he might suffer from any particular or delayed aftereffects. Although he knew that exposure to radioactivity was dangerous to the health, he says that he was confident, even after such strong radiation.

This event, considered to be "significant for protection against radiation," led to a meeting between EDF and the subcontractor in the following days. EDF wrote a report in which it recognized its responsibility but concluded on the absence of consequences for the workers involved in this "significant event." Despite the major dose of radiation to which Julien was exposed, no workplace accidents were reported.

Two months after the accident, Julien had to consult his doctor for a sharp pain in his shoulder. The ultrasound revealed a tumour from B-cell lymphoma, an aggressive cancer, which was already at stage 4 . At age 35 , his prognosis was serious: "I thought I was going to die and I wanted to live, so I didn't make the connection with work right away." He started an especially gruelling treatment: "They gave me the strongest treatment -without

1. The RTR (Régime de travail radiologique) contains all information related to radiological conditions expected at the worksite. It anticipates the doses workers will receive on the job, and is used to make work calendars distributing workers among worksites. 
it I was going to die. I lost my hair, my teeth, I became sterile." During the months of his sick leave and medical care, Julien received a salary of $€ 900$ a month, and heard nothing from his employer or even his colleagues. Accompanied by his partner and their two children, he fought his illness without thinking of the possible connection between his cancer and his job. He left the company in November 2013 with an amicable breach of his employment contract.

It was a little while later, and by chance, that he began looking into occupational illnesses. He was bringing his son to a school skiing trip when he met Louis, who he told about his health problems. Louis was already working with several workers going through the process of having their occupational illnesses recognized, and had spotted other cases of B-cell Lymphoma in nuclear workers. He offered to help him. Without this, Julien would not have taken recourse to the law for recognition of his illness. Like him, his friends and family were far from connecting his nuclear work to his cancer, having mainly provided affective support when Julien's severe illness was diagnosed. Although his pursuit of recognition is largely due to his fortuitous encounter with Louis, he is indebted to friends and family for their precious comfort and new career possibilities once he returned to health. It is thanks to his wife's occupational resources that Julien managed to radically change his line of work. Since 2014, he has been a medical secretary for a practitioner network and, although he had decided "to not drop his [former] employer until he wins his case," nuclear work has seemed far away ever since.

If the intervention of an outsider makes it possible to assess the harm and its connection with the occupation, the support of friends and family (and spouses and life partners in particular) proves to be just as precious in enduring the ordeal of what are often intense treatments, and the reduced capacities that result from them. The (former) workers call heavily on them for the strength to hold on and recover after experiencing a sharp turn in their life course. In Julien's case, the support and succour he received at home allowed him to rebuild his existence by rebounding in a new occupation with which he was satisfied and that he found much more desirable than the previous one.

This study nonetheless found other situations where ill workers did not have the support from friends and family. Some were single and relatively alone when the illness was found. Others who were in a relationship (in some cases with children) at the time went through a separation shortly thereafter. When faced with a serious illness, wives and partners also experience a shock that shakes their familiar world, and the trial can seem to be too much. As other studies have shown (GAYET-VIAUD, LABRUSSE [DE], 2012; MARCHAND, 2016), trying to get health rights recognized and compensated can sometimes appear futile. In the case of nuclear subcontracting, wives and partners may think that they have already "had enough" of this work and its consequences, even more than the (former) workers themselves. 
The biographical approach shows how nuclear work can appear seductive to young workers and couples. The status accrued from working in a prestigious sector is compounded by the pleasure of "real work" and a gratifying income that allows them a comfortable life relative to their qualifications. Engaging in this career thus opens possibilities for workers and their partners, who in many cases enter into a serious relationship and move in together. At the beginning, couples also think they will be able to endure despite the distance, but sooner or later the appeal tends to fade for those who cannot manage to change careers or arrange their mobility more favourably. The pros and cons are no longer balanced, especially when children come into the picture. The income is no longer enough to make up for the challenges of living at a distance, and the traditional polarization of household roles, already widened by nuclear work, becomes a source of frustration and tension. The account is no longer there, the positive expectations of consensual effort turn out to be inadequate, and relationships with friends and family suffer. The strain affects the workers as well as their families, and many couples do not survive. ${ }^{12}$

Moreover, while the constraints of nuclear subcontracting work leave little time and place for worrying about workplace health hazards (it seems that workers and their families are too focused on maintaining relationships), this risk of exposure during maintenance work usually has deferred effects. They manifest in cancer as well as other diseases that workers and their families are not aware of, including reproductive disorders that may in some cases prove to be hereditary. It is only in working with others -the family or an occupational group- that some workers become aware of the dangers and act to stand up for their rights. Although it is invisible, the role played by wives and partners proves to be essential, as much to enduring the arduous demands of the work as to becoming aware of its risks. Unlike occupational pathologies that are identified occupational hazards, like silicosis for coal miners (ROSENTAL, 2009), the individualization and destabilization of working situations and the "privatization" of health issues by nuclear institutions (GUSFIELD, 2009) are still impediments to an awareness of radiation-induced illnesses as a collective problem, inherent to the working conditions of the nuclear industry.

12. This observation was established in the 1990s (DonIOL-SHAW et al., 2001), and this study confirms it. 


\section{REFERENCES:}

BARrÈre-Maurisson, M.-A. (1984). « Le cycle de la vie familiale. Méthodologie et champ d'utilisation. » In Collectif, Le Sexe du travail. Structures familiales et système productif (pp. 29-43). Grenoble: Presses universitaires de Grenoble.

Battagliola, F. (1999). « Des femmes aux marges de l'activité, au cœur de la flexibilité. » Travail, genre et sociétés, 1, 157-177.

BIDET, A. (2010). «Qu'est-ce que le vrai boulot? Le cas d'un groupe de techniciens. » Sociétés contemporaines, 78, 115-135.

Bidet, A., Gayet-Viaud, C. \& Le Méner, E. (2013). «L'ethnographie en trois dimensions. Entretien avec Jack Katz. »La Vie des idées. Online http://www.laviedesidees.fr/IMG/ pdf/20130521_1_ethnographie_en_trois_dimensions_version_inte_grale_1_.pdf (accessed 10 March 2017).

Bonnet, E., Collet, B. \& Maurines, B. (2006). « Carrière familiale et mobilité géographique professionnelle. » Cahiers du genre, 41, 75-98.

BoudiA, S. (2009). « Les problèmes de santé publique de longue durée. Les effets des faibles doses de radioactivité. » In G. Gilbert, E. Henry (Eds.), Comment se construisent les problèmes de santé publique (pp. 35-53). Paris: La Découverte.

Boudia, S., Fellinger, A. (2007). « Radioactivité et santé au travail : trajectoire historique d'un problème. » Histoire et sociétés, revue européenne d'histoire sociale, 23, 32-43.

Bouffartigue, P., Pendariès, J.-R. \& Bouteiller, J. (2010). «Virilité, métier et rapport aux risques professionnels : le cas de travailleurs de la sous-traitance. »Perspectives interdisciplinaires sur le travail et la santé, 12(3). Online https://pistes.revues.org/2652 (accessed 10 March 2017).

BREVIGLIERI, M. (2012). « L'espace habité que réclame l'assurance intime de pouvoir : un essai d'approfondissement sociologique de l'anthropologie capacitaire de Paul Ricœur. » Études riccuriennes, 3(1), 34-52.

CEFAÏ, D., TerZI, C. (Eds.) (2012). L'Expérience des problèmes publics. Paris: Éditions de l'École des hautes études en sciences sociales.

Clot, Y. (2010). Le Travail à cœur. Pour en finir avec les risques psychosociaux. Paris: La Découverte.

Cardis, E., Vrijheid, M., Blettner, M., Gilbert, E., Hakama, M., Hill, C., ...Veress, K. (2005). "Risk of Cancer After Low Doses of Ionising Radiation: Retrospective Cohort Study in 15 Countries." British Medical Journal Online First. Online http://www.bmj.com/content/ bmj/331/7508/77.full.pdf (accessed 10 March 2017).

CorteEl, D., Le LAY, S. (Eds.) (2011). Les Travailleurs des déchets. Toulouse: Érès.

Cottereau, A. (1983). « Usure au travail, destins masculins et destins féminins dans les cultures ouvrières, en France, au XIX ${ }^{\mathrm{e}}$ siècle. » Le Mouvement social, 124, 71-112. 
Daubas-Letourneux, V., Frigul, N., Jobin P. \& Thébaud-Mony A. (Eds.) (2012). Santé au travail : approches critiques. Paris: La Découverte.

Daubas-Letourneux, V., Thébaud-Mony, A. (2001). « Les angles morts de la connaissance des accidents du travail. » Travail et Emploi, 88, 25-42.

Dejours, C. (1993). Travail : usure mentale. Essai de psychopathologie du travail. Paris: Bayard.

Dewey, J. (2010). Le Public et ses problèmes. Paris: Gallimard.

Doniol-Shaw, G., Huez, D. \& SAndret, N. (2001). Les Maux de la sous-traitance. Enquête Sted, 1993-1998, suivi sur 5 ans des salariés de la sous-traitance nucléaire. Toulouse: Octarès.

Felstiner, W. L. F., Abel, R. L. \& SARAT, A. (1991). «L'émergence et la transformation des litiges : réaliser, reprocher, réclamer. » Politix, 16, 41-54.

Fournier, P. (2000). «Les "kamikazes" du nucléaire : un même mot pour une réalité qui change. » Sociétés contemporaines, 39, 135-152.

FOURNIER, P. (2012). Travailler dans le nucléaire : enquête au cœur d'un site à risques. Paris: Armand Colin.

Gayet-Viaud, C., Labrusse (DE), A. (2012). «Itinéraires de victimes d'accidents du travail et de maladies professionnelles. Freins et entraves à la mobilisation pour les droits à la santé et à la réparation. » In C. Courtet, M. Gollac (Eds.), Risques du travail. La santé négociée (pp. 123-142). Paris: La Découverte.

GHis MALFILATRE, M. (2017). « La CGT face au problème de la sous-traitance nucléaire à EDF. Le cas de la mobilisation de Chinon (1987-1997). » Sociologie du travail, 59(1). Online http:// sdt.revues.org/570 (accessed 10 March 2017).

Gollac, M., Volkoff, S., (2006). « La santé au travail et ses masques. » Actes de la recherche en sciences sociales, 163, 4-17.

Gotman, A. (1999). « Géographies familiales, petites migrations et génération. » In C. Bonvalet, A. Gotman \& Y. Grafmeyer (Eds.), La Famille et ses proches. L'aménagement des territoires (pp. 69-133). Paris: Presses universitaires de France/Institut national d'études démographiques.

Gusfield, J. R. (2009). La Culture des problèmes publics. L'alcool au volant : la production d'un ordre symbolique. Paris: Economica.

HATZFELD, N. (2009). «Les maladies du travail face au déni administratif : la longue bataille des affections périarticulaires (1919-1972). » Revue d'histoire moderne et contemporaine, 56-1, 177-196.

HeCHT, G. (2004). Le Rayonnement de la France. Énergie nucléaire et identité nationale après la Seconde Guerre mondiale. Paris: La Découverte.

Hecht, G. (2016). Uranium africain, une histoire globale. Paris: Seuil.

Henry, E. (2007). Amiante, un scandale improbable. Sociologie d'un problème public. Rennes: Presses universitaires de Rennes. 
JEAnJEAn, A. (2011). «Entre transmission, contagion, secret et transgression : ce que l'on se "passe" aux abords des déchets. » In D. Corteel, S. Le Lay (Eds.), Les Travailleurs des déchets (pp. 279-300). Toulouse: Érès.

Jobin, P. (2012). « Fukushima ou la radioprotection, retour sur un terrain interrompu. » In V. Daubas-Letourneux, N. Frigul, P. Jobin \& A. Thébaud-Mony (Eds.), La Santé au travail. Approches critiques (pp. 83-104). Paris: La Découverte.

JouZEL, J.-N. (2009). « Encombrantes victimes. Pourquoi les maladies professionnelles restentelles socialement invisibles en France ? » Sociologie du travail, 51(3), 402-418.

MARChAND, A. (2016). «Quand les cancers du travail échappent à la reconnaissance. Les facteurs du non-recours au droit. » Sociétés contemporaines, 102, 103-128.

Marchand, A., Rollin, Z. (2015). « Ce que l'intervention fait à la recherche dans un contexte de maladie grave. » Santé publique, 27(3), 331-338.

Paugam, S. (2007). Le Salarié de la précarité. Les nouvelles formes de l'intégration professionnelle. Paris: Presses universitaires de France.

PiTTI, L. (2010). « Experts "bruts" et médecins critiques. Ou comment la mise en débats des savoirs médicaux a modifié la définition du saturnisme en France durant les années 1970. » Politix, 91, 103-132.

Rosental, P.-A. (2009). « De la silicose et des ambiguïtés de la notion de "maladie professionnelle". » Revue d'histoire moderne et contemporaine, 56-1, 83-98.

Rosental, P.-A., Devinck, J.-C. (2007). «Statistique et mort industrielle. La fabrication du nombre de victimes de la silicose dans les houillères en France de 1946 à nos jours. » Vingtième siècle. Revue d'histoire, 95, 75-91.

Schwartz, O. (1990). Le Monde privé des ouvriers : hommes et femmes du Nord. Paris: Presses universitaires de France.

Stavo-Debauge, J. (2012). « Des “événements" difficiles à encaisser. Un pragmatisme pessimiste. » In D. Cefaï, C. Terzi (Eds.), L'Expérience des problèmes publics (pp. 191-223). Paris: Éditions de l'École des hautes études en sciences sociales.

Testenoire, A. (2006). «Éloignés au quotidien et ensemble. Arrangements conjugaux en milieu populaire. » Cahiers du genre, 41, 117-138.

ThÉBAud-Mony, A. (1991). De la connaissance à la reconnaissance des maladies professionnelles en France : acteurs et logiques sociales. Paris: La Documentation française.

ThÉBAud-Mony, A. (1992). « La connaissance des maladies professionnelles. » Travail et Emploi, 54, 87-99.

ThÉBAud-Mony, A. (2000). L'Industrie nucléaire : sous-traitance et servitude. Paris: Inserm.

VignAL, C. (2005). «Injonctions à la mobilité, arbitrages résidentiels et délocalisation de l'emploi. » Cahiers internationaux de sociologie, 118, 101-117.

Zonabend, F. (1989). La Presqu'île au nucléaire. Paris : O. Jacob. 